\title{
Assessment of Safety Practices among Modern Barbers in Gwadabawa Local Government, Sokoto State, Nigeria
}

\section{${ }^{*}$ SARKINGOBIR, Y; ${ }^{1}$ NAHANTSI, MS; ${ }^{1}$ YARIMA, SA; ${ }^{1}$ ADILI, SI; ${ }^{2}$ BELLO, MM; ${ }^{3}$ MALAMI, Z}

\author{
${ }^{I}$ Department of Biology, Shehu Shagari College of Education, Sokoto State, Nigeria \\ ${ }^{2}$ Dental Department, Sultan Abdurrahman College of Health Technology Gwadabawa, Sokoto State, Nigeria \\ ${ }^{3}$ Medical Laboratory Science Department, Sultan Abdurrahman College of Health Technology Gwadabawa, Sokoto state, Nigeria \\ *Corresponding Author Email: superoxidedismutase594@gmail.com; Tel: +2349096266980
}

\begin{abstract}
Many people attend barbing shops for personal care on frequent basis. Despite the frequent patronage of barbing shops, so many risks and hazards are possible. This paper intended to determine the safety practices of modern barbers in Gwadabawa local government, Sokoto state, Nigeria .A cross-sectional survey type of study was conducted. Therein, fifty respondents were interviewed using semi-structured questionnaire and their shops were inspected .Summarily, poor safety practices among the respondents were revealed. It is pertinent that, the government, advocators, and health bodies, facilitate the training and regulation of barbing workers.
\end{abstract}

DOI: https://dx.doi.org/10.4314/jasem.v23i3.6

Copyright: Copyright $@ 2019$ Sarkingobir et al. This is an open access article distributed under the Creative Commons Attribution License (CCL), which permits unrestricted use, distribution, and reproduction in any medium, provided the original work is properly cited.

Dates: Received: 01 January 2019; Revised: 21 February 2019; Accepted 20 March 2019

Keywords: Barbers, bacteria, viruses, hair, haircut, safety practices

The scalp of human being nearly contains 300,000 hairs with a growth rate of half an inch per month. Thus, necessitating the need for visiting a barber's shop at least every month for haircut personal care (Omoruyi and Idemudia, 2011). This triggered the enlargement of barbing industry, which is mostly operated by people with little knowledge/ awareness on safety practices and it is indeed a way that subjects clients and operators to risk of contracting various diseases and infections (Kondo et al ., 2006; Oyedunni and Adesoro, 2009). The word "barber" emanates from Latin word "barba" meaning beard .Barber is a person who engaged in an occupation of cutting ,trimming , and shaving of hair or beard .In the past ,the barbers provide several services, such as, tooth drawing , sensorial operations, cauterization etc. Whereas, with the advance of science and technology, they become less patronized and less popular (Wazir et al., 2008). Many health problems including communicable and skin infections are associated with the profession of barbing. Thus, the possibility of affecting visitors and even barbers themselves (Wazir et al., 2008).Infection is still the main trigger of mortality and morbidity among humans especially in the underdeveloped nations .It accounts for $25 \%$ of all human deaths .Whereas, ccommunicable infections are mostly occurring in the low-income countries (Kumar et al., 2005). To control the tendency of disease / infection transmission, barbers ( personal caregivers) should supply safe, competent and hygienic services in clean premises, because failure to do that can jeopardize the health of clients, barbers and even the community (the public at large) (Wazir et al., 2008). Instruments that can penetrates the body (e.g. clipper blade) become contaminated when not properly cleaned before or after use .The next receiving person is at risk. Even the operator can have an accident, which can lead to disease contraction .Contact between contaminated blood or body and instruments, then cuts, sores or broken skin ,can trigger infection.A blood or microbes does not have to be plainly visible on the instrument in order to present a risk of infection; thus the need for care and safety practices during barbing work (Victorian Government Publishing Service ,2004; Australian Society for HIV Medicine, 2013). Contamination through barbing may occur when (i) Strict hygiene is not observed by the operator (ii) Same equipment or materials are shared (iii) Clean materials or instruments contacted the unclean ones (iv) Contaminated materials, equipment or waste are not disposed-off properly (v) Structural facilities, furnishings and fittings of the workplace are not cleaned between clients or works (vi) Towels and other materials are not changed or properly cleaned ( VGPS , 2004) . 
Blood-borne infections of hepatitis B, C and HIV can be transmitted through barbing. It is moderately risky to communicate them through sharing of personal care materials like razor ,and other barbering equipment. Although, it is very risky to transmit HIV, through equipment that penetrate the body (ASHM, 2003). In Gwadabawa local government Sokoto state, there is noticeable change of haircut patronage from ordinary knife or razor workers (ma aska / traditional barbers) at home or other places to that of modern barbers; where a shop is reserved for that purpose. They use clippers, more advanced and organized system than the immediate one .But, the data on how barbers imbibe safeness is limiting, in spite of possible risks and hazards to health of the public ( Omoruyi and Idemudia , 2011). Consequently, the objective of this paper is to explore the safety practices of modern barbers in Gwadabawa local government, Sokoto state, Nigeria.

\section{Materials ANd Methods}

Description of study area: The study was conducted in Gwadabawa local government of Sokoto state, Nigeria. Gwadabawa is located between Kware, Illela, Tangaza, Gada, and Wurno local governments. It has a total area of $991 \mathrm{~km}^{2}$ (383sqm), and a total population of 231,358 according to 2006 census data. Most of the inhabitants of Gwadabawa are Muslims by religion, and Hausa-Fulani by tribe .The major occupations are: farming, trading, livestock keeping, civil servant and quasi. Gwadabawa is blessed with Sultan Abdurrahman College of Health Technology, one general hospital and many healthcare facilities.

Data collection and treatment: Descriptive survey and convenience sampling were utilized in this study. Therein, semi structured questionnaires were used to record data of the fifty study participants (interviewed respondents) and their various workplaces (inspected places).

Analysis of data: The data collected was analysed using thematic content analysis (thematic networks) with the aid of Microsoft excel.

Statistical inference use: Thematic content analysis carried out on the data of this study revealed poor safety practices of modern barbers in Gwadabawa local government, Sokoto state, Nigeria.

\section{RESULTS AND DISCUSSION}

Table 1 ,shows that the level of education of $40 \%$ of the respondents is S.S.C.E, which is low . Whereas , the majority of the respondents $(60 \%)$ are having diploma in health field.This is a good omen and should serve as motive to inculcate safety behaviours during their practices. From table 2, 60\% of the respondents received no special health training concerning barbing .All the respondents $(100 \%)$ echoed that ,there is no government or its agency that is regulating their practices and no awareness or training was accorded to them .Reports were saying that, in developed countries barbers are regulated through constant training, licensing and laws .But in developing countries it is on the contrary (Spengane et al ., 2018).This is what is happening in Sokoto, Gwadabawa local government.

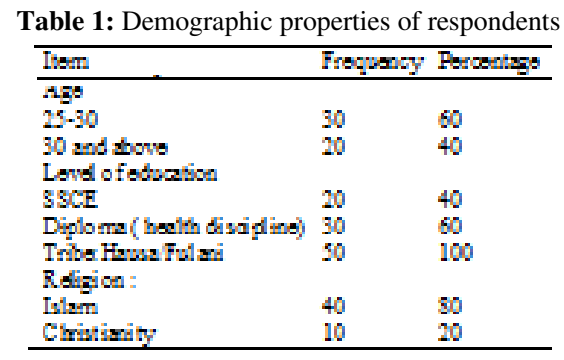

All the respondents believed that, it is possible to transmit infections through barbing. Whereas, $80 \%$ agreed that even the barber can contract infections during his work. Table 3 shows the behaviours of workers in their respective shops.All of them were not keeping records of their work (e.g. equipment record, client record, accident record, services record etc.). Keeping records is very important. It has many values, like helping in tracing source of hazard or risk, and tracing of exposure (VGPS, 2004). On sterilization, all the respondents admitted that, they treat their equipment. $40 \%$ always sterilized, $40 \%$ sterilized sometimes, and $10 \%$ sterilized when they feel there is risk or hazard .The methods of sterilization are using flame or spirit . There is no much evidence on efficiency of the flame which barbers used in sterilization in Africa .Spirit contains (95\%) ethyl alcohol and 5\% methyl alcohol, which are not virucidal, consequently ineffective on viruses like hepatitis and HIV (Spengane et al., 2018). All the respondents are not wearing coverall, but they always cover their clients with towel. Likewise, all of the respondents were not taking prophylactics or vaccinations .VGPS (2004) recommends that clients and workers should wear coveralls during services. So also prophylactics use and vaccinations should be embraced routinely because of accidents.

Table 4, shows the organization of respondents shops and practices. $40 \%$ clean shops when they felt they were dirty .60\% always clean shops before opening for a day work .All respondents admitted that, the clients towels and coveralls are been kept in the shops.This 
may help in impeding the transport of microbes to homes .Respondents working time was $10 \mathrm{am}-12 \mathrm{pm}$ daily. $30 \%$ of workers said, few clients come with personal clippers .In terms of water accessibility, $60 \%$ of the shops have accessibility. Water is essential for cleaning of equipments and hygiene of body whenever required. Thus it should be available.

Table 2: Basic knowledge of respondents pertaining their jobs

\begin{tabular}{lll}
\hline Item & Frequency & Percentage \\
\hline Have you received special health training or aawareness? No & 30 & 60 \\
Is government or health agency regulating your actions? No & 50 & 100 \\
Do you receive any awareness or training from government? No & 50 & 100 \\
It is possible to transmit diseases to the client through barbing? Yes & 50 & 100 \\
It is possible to transmit diseases to the barber through barbing? Yes & 40 & 80 \\
\hline
\end{tabular}

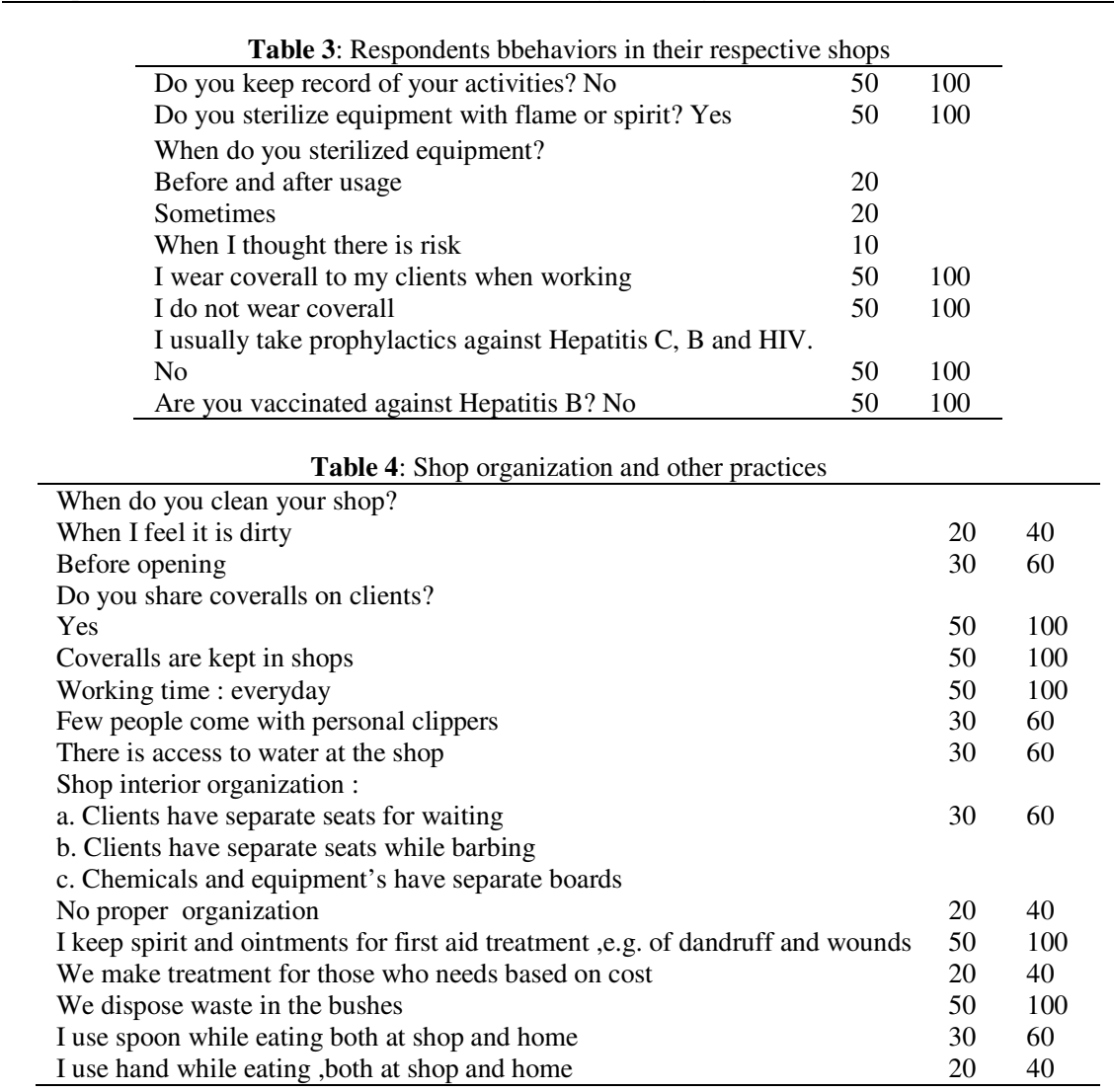

The shops of $30 \%$ of workers are more organized, they have equipment and chemicals board, a section for operation (haircutting), and a section for sitting for clients in the queue. Whereas, $20 \%$ were less organized $.40 \%$ of the workers asserted that, they make treatment according to cost (payment).For example, there is treatment for dandruff .And $100 \%$ of them keep spirit and ointments for first aid handling of cuts and relations. In terms of waste, they all echoed that, they gather it at the outside of shops and transport it to the bushes for discarding. Hair is (the half of its diameter is less than 10 micrometers) very tiny, during improper disposal, like the field one, it can be transmogrified to more tiny particles that are harmful. These particles irritates the eye ,nose and throat .People with lung or heart problems are at the risk of visiting hospitals and in some cases deaths because of particulate pollution ( United States of America Environmental Protection Agency, 2003). Some of the respondents $(30 \%)$ admitted that they use spoon to eat both at home and shops. Whereas $40 \%$ use bare hands. Barbing is a practice that is very vital in the society .Many people patronize it regularly .It is also a practice associated with risks and hazards that are threat to individual and public health .It is criticized as the vehicle that help in spread of infections like hepatitis $\mathrm{B}, \mathrm{C}$, dermatitis, scabies, ringworm and other skin diseases that their mode of transmission is contact with personal care items (Wazir et al., 2008). Transmission is possible in barbing during shaving, combing, hair shaping, etc. Therein; it is easy to make cuts, wounds on pimples or skin. Thus, it requires regular care and 
safety behaviors (David et al., 2011; Omoruyu and Idemudia, 2011).Government, health bodies and practitioners, advocates should feel it as responsibility to enlighten, train and regulate barbing for the benefit of society.

Conclusion: Modern barbers in Gwadabawa local government area exhibits poor safety behaviors in the course of their work. There should be proper healthrelated training or workshop or awareness to the barber's .This is the burden of government, health related bodies and practitioners. There should be laws to guide safety and practice of barbing like in other countries. The public should be enlighten on the risks associated with barbing practices.

\section{REFERENCES}

Australian Society for HIV Medicine (2013). Correctional officers and blood borne viruses' .LMB 5057 Darling just NSW1300 .Retrieved from www.ashm.org.au/publications

David, LK; Janes, HO; Juan, C; Nanteza, S; Kenneth, $\mathrm{O}$ (2011). Barber's activities in the main streets of Gulu, northern Uganda: implication for HIV transmission J. Medicine and Medical Science, 12(9):1114-1122

Kondo, M; Nakano, N; Shiraki, Y (2006). A ChineseJapanese boy with black dot ringworm due to Trichophyton Violaceum .J. Dermatology, 33(3):165-168

Kumar, PM; Clark, MK (2005). Clinical medicine .6th EDI. Elsevier Saunders.
Omoruyi, MI; Idemudia, MI (2011). Comparative analysis of antiseptic properties of some disinfectants on bacteria and fungi of public health important isolated from barbing clippers .J. of Asian Scientific of Research, 1(2), 65-68

Oyedunni, S; Adesoro, M.(2009). Potential risk of HIV transmission in barbering practice among professional barbers in Ibadan, Nigeria .African Health Sci. 9(1):19-25

United States of America Environmental Protection Agency (2003). Air quality guide for particulate pollution. Office of air and radiation (6301A) EPA 452/f-03-002. Retrieved from www.epa.gov/airnow.

Wazir, SM; Mehmood, SA; Ahmed, A; Jadoon, RH (2008). Awareness among barbers about health hazards associated with their profession .J. Ayub Medical College Abbot. 20 (2):35-38.

Spengane, M; Korsman, S; Mkentane, K; Davids ,KM; Zemawy ,W; Mbhele, S; Nicol, M; Gumedze, F; Ngwanya, D; Khumalo, NP (2018). Blood and virus detection on barber clippers. South African Medical J. 108 (4):278-282.

Victorian Government Publishing Service (2004). Health guidelines for personal care and body art industries .Snap printing, 673 Spencer Street, West Melbourne. Retrieved from www.health .Vic.gov.au/ideas. 